\title{
Sound Links: \\ Exploring the social, cultural and educational dynamic s of music al communities in Australia
}

\author{
DrBrydie-Leigh Bartleet \\ Queensland Conservatorium Research Centre Griffith University
}

\begin{abstract}
Sound Links examines the dynamic of community music in Australia, and the models it represents for informal music leaming and teaching. This involves researching a selection of vibrant musical communities across the country, exploring their potential for complementarity and synergy with music in schools. This artic le foc uses on the most signific ant themes that have emerged from the author's recent Sound Links fieldwork in four music al communities across Australia. Drawing on insights from well over 300 community music practitioners, participants, educators, and administra tors, it will touch on the critical success factors, key challenges, leaming dynamic s and models for community-school collaborations found in these diverse community settings. These themes will be interwoven with ideas and concepts from community studies in the humanities and community music literature to provide a range of insights into the social, cultural and educ ational dyna mic s of music al communities in Austra lia.
\end{abstract}

\section{Keywords}

community music

leaming dynamics

community-school collaborations 


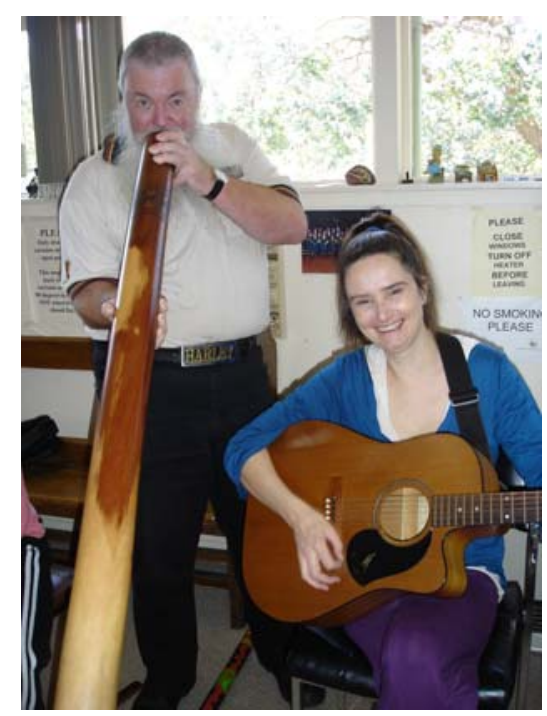

Figure 1: Attitude Music Therapy Program, Dandenong Ranges Music Counc il, Victoria.

I am sitting on the outskirts of a circle that has been formed by Attitude participants at the Dandenong Ranges Music Council. This is a weekly community music therapy session which is run for people with special needs. The group is led by a music thera pist who sings and plays guitar, and her assistant who plays didjeridu. They sing songs about mother earth and adapt the lyrics to fit in with local places that are sentimental to the group. All a re encouraged to get involved, whether by singing a long, making up the lyrics, shaking a set of bells or keeping time with a set of clap sticks. As I quietly sing along I am mesmerized by the looks of delight on the participant's faces. This is a profoundly moving example of Australian community music in action; where a diverse group of people, who are often marginalized from society, are given the opportunity to actively engage with music-making in a dynamic community environment.

(Bartleet Fieldnotes, 13 September 2007, Dandenong Ranges, Vic toria)

\section{Introduction}

This opening field note entry was written during one of my recent field work trips for the Sound Links study. This Australia Research Council funded project is examining the dynamics of community music-making in Australia, and the models it represents for informal music leaming and teaching. ${ }^{1}$ This project is focusing on six vibrant musical communities in the Dandenong Ranges (Victoria), Albany (Westem Australia), McLaren Vale (South Australia), Fairfield (New South Wales), Borroloola (Northem Teritory) and Inala (Queensland), and exploring their potential for

${ }^{1}$ So und Links is a project of Queensland Conservatorium Research Centre, Griffith University, in partnership with the Music Council of Australia, the Australian Music Association, and the Australian Society for Music Education. It is supported by the Australia Research Council's Linkage scheme. The research team for the project consists of Professor Huib Schippers (Queensland Conservatorium Research Centre, Griffith University), Associate Professor Peter Dunbar-Ha Il (University of Sydney), Dr Ric hard Letts (Music Council of Australia), and Dr Brydie-Leigh Bartleet (Queensland Conserva torium Research Centre, Grffith University). 
complementarity and synergy with schools in their local areas. The project spans a period of two years, commencing in 2007 and concluding in 2008. At the time of writing this article four of the six vibrant music al communities have been visited, with the last two scheduled for mid-2008. The criteria used to identify these vibrant communities are detailed below.

In this paper I give an introduction to the study and position it within the broader context of Australian community music and education. I then briefly outline three of the most striking themes that have emerged in my fieldwork visits, namely inspining leadership from within the community, vibrant community collaborations, and embracing cultural diversity. Finally, I briefly touch on the leaming dynamics and models for community-school collaborations which have emerged in the preliminary a na lyses of these community settings.

While there have been numerous debates about what constitutes community music, it is widely acknowledged that it is a group activity where people jo in together to actively partic ipate in the music-making process. It encompasses a wide and diverse range of musics, which reflect and enrich the cultural life of the participants and their broader community. While there is nothing substantially new or novel about community music-making, there is a growing a wareness and recognition of the connections between community musicians, music making, and education. As Veblen and Olsson suggest, 'This broadening of vision for music educators promises many opportunities for research, such as investigating the variety of successful teaching and leaming strategies found in Community Music settings' (2002: 743). Despite the promise of such a vision, in the Australian context, only a minimal amount of research has examined community music settings, and their potential to enrich practices in music education.

\section{Background: The Australian context}

Despite this lack of research, over the past 20 to 30 years a diverse range of community music practices have grown in Australia, and played a significant role in the wide and varied musical landscape of this country. As the Australia Council describes in the discussion paper, 'Planning for the Future: Issues, Trends and Opportunities for the Arts in Australia':

The musical landscape in Australia today is broad and diverse, consisting of different cultural traditions, genres and practices. Increasingly, previously defined boundaries between musical genres a re being crossed and exciting new genres are being created. Australia, with its multicultural make-up, is uniquely placed to lead the world in this development. The many interrelated layers that contribute to this musical landscape include grassroots music-making, music education, youth music practice, a mateur music practice, moving through opportunities offered for professional development, to emerging artists, through community music practice and peak youth bodies, to professional artists and orga nizations creating and presenting music of the highest quality. (2001: 44)

A quick scan of the Music Council of Australia's Community Music Bulletin, affims this vibrancy and high level of activity in the community music sector, as does the recent response of over two 
hundred entrants in the inaugural 'Music in Communities Awards' run by MCA's Music. Play for Life. Entrants included choirs, music therapy programs, Indigenous groups, bands, festivals, orchestras, regional conservatoriums, country music clubs, samba schools, folk clubs, drumming circles, thistle pipe bands, studio recording projects and community music organisations, to mention just a few. The Australian Govemment's culture and recreation portal also lists a large number of community music projects that range from Indigenous music to country, folk, rock, jazz, military and ethnic musics. Some states also have community cultural development organizations, and Regional Arts Australia and its State and Temitory organizations also provide strong support to community arts programs, including community music. However, this high level of activity is not without its problems. In the Australia Council's recent Community Partnerships Scoping Study Report, Creative Communities, Dunn (2006) identifies a number of challenges facing musicians and the music sector, ranging from a devaluing/worsening of music education, music not being seen as integral to life/culture/wellbeing, a lack of support and recognition for certain groups including grassroots and community, and inequity in the division of the funding and resourc ing pie.

Somewhat sumprisingly, the aforementioned high levels of community music activity and considerable challenges have not been paralleled with much in-depth research. Notwithstanding the significant contributions of Hawkins' (1993) study on community arts in Australia, Breen's (1994) study on public funding of community music in Australia, Harrison's (1996) overview of community music in Australia, Cahill's (1998) handbook on developing music projects and organisations, and Coffman's (2006) study of adult community band members in Tasmania, in-depth research into community music in this country has been minimal. While we know there are high levels of activity a cross the country, the cultural and social contexts of these activities and their connections to the broader community and schools rema in open for further research.

A similar situation can be found from an educational perspective, where considerable research has been devoted to formal Australian school music programs and their cumicula, including the recent National Review of School Music Education (DEST 2005). However, much less is known about Australia's informal community contexts and their approaches to leaming and teaching music. As Myers (1992) argues, there is a need to think beyond the school level, as the emerging needs of society require an expanded view of education, one that nurtures the lifelong leamer. The Australia Council reiterates this by highlighting, 'that the formal education system is only one means of influencing the attitudes of children and that it cannot be expected to bring about significant change in isolation' (2000: 90). Recognition of this did reach the general brief of the National Review of School Music Education, which acknowledges that 'communities play a vital role in effective music education' (DEST 2005: vii); however, the final report still primarily focuses on music in schools. With this in mind, the Sound Links project aims to build a synergy with the outcomes of the National Review, and enhance our understandings of Australian community music and education. 


\section{Methodology Outlining the ethnographic approach}

To accommodate the a ims of the research project, a combination of qualita tive methodologies, including ethnographic case studies, and quantitative methodologies, including a nation-wide survey, have been used. This paper focuses specific ally on the ethnographic case study findings, including insights from our field visits, semi-structured interviews, focus groups, participant and non-participant observations, and analyses of relevant documentation. This particular methodological approach lends itself well to uncovering the individual stories of the community musicians and educators, the dynamic s of their practice, and the broader socio-cultural issues and structural frameworks that arise from these settings. As Higgins concurs, 'ethnographic strategy and method unmask the traits of Community Music in action' (2006: 265, emphasis added). In order to fine tune our ethnographic approach and trial it in a local community music environment, a pilot study was successfully undertaken with the Queensland Youth Orchestras program in Brisbane.

Because an ethnographic approach focuses on openness and reciprocal exchange, with its point of departure being the lived experiences of the researched, it was necessary for the research team to come face-to-face with the participants themselves. Full ethical clearance has been given by Griffith University to undertake this research, and participants have given 'informed consent' for their identities and words to be used in resulting public ations. This allowed the research team, entering into a close interaction with the community musicians and educators in their everyday musical lives, to better understand their beliefs, motivations, and behaviours (see Tedlock 2000: 455). In order to facilitate this, a large a mount of forward planning was necessary. In each community I identified a key facilitator who had significant local knowledge and a wide network of contacts within the community. In the Dandenong Ranges this was the executive officer at the music council, in Albany this was the senior teacher at the local high school, in McLaren Vale this was the head of performing arts at the Lutheran College and in Fairfield this was a senior member of the cultural policy team at the local city council. These key people introduced me to a number of community musicians, educators and groups, which not only made the organization of the trips more efficient, it also enabled me to tap into local knowledge and cover the community's activities in greater depth.

Each fieldwork trip lasted five days, and we conducted approximately 30 interviews or focus groups with 60-100 partic ipants. These partic ipants included primary school students, secondary school students, school music teachers, principals, parents, community music facilitators, community music participants, cultural development workers, youth workers, settlement workers, festival organizers, local council workers, instrument repairers, radio presenters, and music retailers. As the focal point of each interview was the participant's individual stories, we used semi-structured interviewing techniques, where we had a list of questions we wanted to ask, but allowed the conversation to detemine how the information was obtained (see LevesqueLopman 2002). These questions were drawn from the research team's extensive expenience in community music and education, issues raised in the online survey, ideas discussed at a Sound 
Links workshop run at the Australian Society for Music Education's national conference, and broader theoretical ideasidentified in the literature.

We also attended rehearsals and performances in a variety of settings, such as community centres, schools, churc hes, sports fields, recording studios, farmers' markets, arts centres, galleries, teaching studios, hospitals, halls, clubs, and temples. We visited local councils and community centres to gather documentation about the broader communities surrounding the music activities we were studying. The research also went beyond the more formalized interviews and observations; we shared many coffees, post-rehearsal drinks, as well as family meals with partic ipants in some of the communities, particularly when I was travelling on my own. At times we were hauled into the action and handed various instruments to try out, other times we were told to sing along, and on two occasions I had to dance with the groups we were studying. We also attended church services, radio interviews, book launches and other social occasions, including a civic ceremony held by the mayor of Albany to welcome me to the town. All of these experiences led to new insights about the people involved, the broader communities and how music functions within these settings. As ethnography is a method that is about forming relationships, these interactions were obviously significant, but could never be exactly reproduced; as such, each community case study was subtly different (see Behar 1999: 480). Likewise, the research team a Iso differed slightly from trip to trip. I attended each fieldwork visit to ensure a consistency of approach; however, sometimes I was on my own, other times I was accompanied by different team members, and these changes in personnel subtly influenced the dynamic s of our interactions with the community musicians. It is also worth mentioning that each of the team members has been actively involved in community music-making; in fact, we often drew on our 'insider' status as a point of introduction and a point of common ground with the participants. This meant sharing our own experiences during interviews, sometimes giving advice other times a sking for guidance.

The first analysis phase - and I emphasize first, as two more case studies still need to be completed - has involved identifying a number of key themes and coding and sorting the data into these categories. Some of these themes or categories arose spontaneously from the participants themselves, other concepts arose whilst we were immersed in the experience of fieldwork, and further ideas have been generated from the literature. This process of a nalysing and then writing about this ethnographic research has also called for a balance between the individual participants' stories and a broader social critique. 


\section{Defining the community contexts}

Selecting the locations and parameters of the study was a challenging process that brought to the surface a number of debates about the 'definition issue', which have been documented extensively in the literature on communities and community music. As Elliot, Higgins and Veblen explain, the concept of community music is 'situated, contested, contingent, and hard to pin down' (2008: 3), hence making the selection of field sites a complex and complic ated process. I'm not suggesting that I re-open the debate that has been going on for many years about what community music is. As Higgins, amongst many others has argued, disc ussions of definitions can lead community music into a 'disc ursive cul-de-sac' where insights into both practice and theory are limited (2006: 2). While I agree with Higgins' argument, when it came to selecting the locations we would study, our own conceptions (and dare I say definitions) of community music did require nigorous critique in order for us to reach a productive discussion about what we were studying, what we were hoping to find out, and where we thought we should visit. As different research questions require different definitions, we had to make sure that ours were aligned for this partic ular project's focus. Of course, each member of the research team also brought their own assumptions to the discussion, as did the project's industry partners with their extensive network of community music organizations. As Mason (2000: 19) explains, concepts of community are complex because they involve a number of different elements, and people interpret these elements differently, or weight the presence or absence of them differently, and hence disagree over what counts as a community. When choosing the locations, debates raged about whether small isolated 'communities of interest,' such as our pilot study with the Queensland Youth Orchestras, should be included in this project, given that their level of interaction with what many would perceive as their broader community is sometimes modest. Likewise, the team debated about whether festiva ls and annual events could be included, given that they often cater to audiences outside the local community and do not necessarily service the local community on an ongoing and regularbasis.

In the end, we had to embrace the 'slipperiness' of this concept, but at the same time make sure we didn't become too vague and variable in how we used it. As Amit \& Rapport (2002) caution, expressions of community require sceptic al investigation, rather than providing a 'readymade social unit upon which to hang analysis' (2002: 13-14). Likewise, Elliot, Higgins \& Veblen (2008: 3) suggest 'community music is a complex, multidimensional, and continuously evolving human endeavour.' Taking into account the slipperiness and ever-evolving nature of the concept, we did agree on a number of essential elements we wanted the communities we were studying to have. Firstly we were keen to visit community music programs, of whatever style of genre, that included a group of people who had a sense of common interest for which they assumed mutual responsibility, who acknowledged their interc onnectedness, who respected the individual differences among members, and who committed themselves to the well-being of each other and the integrity and well-being of the group (Wood \& J udikis 2002: 12). Following Cahill's definitions, we also looked for community music programs which were 'owned' by the local community, with a 'management committee or board [that] is elected from within that community' (1998: vii). Following Higgins' suggestion that community music revolves a round 
'people, participation, places, equality of opportunity and diversity' (2006: 83), we also wanted to study community music activities which connected with the broader community - whether that broader community is defined in tems of geography, interest, ethnicity, and so on - and were aware of their 'place' within that broader social, cultural, and oftentimes economic context. This led us to select communities that were widely dispersed geographically, as indic ated on the following map (see Figure 2). These communities also represent a cross-section of Australian social contexts, including a culturally diverse urban city (Fairfield), a middle class suburban location (Dandenong Ranges), a remote Indigenous setting (Borroloola), an urban Indigenous setting (Inala), a small rural town (McLaren Vale), and a large established regional centre (Albany).

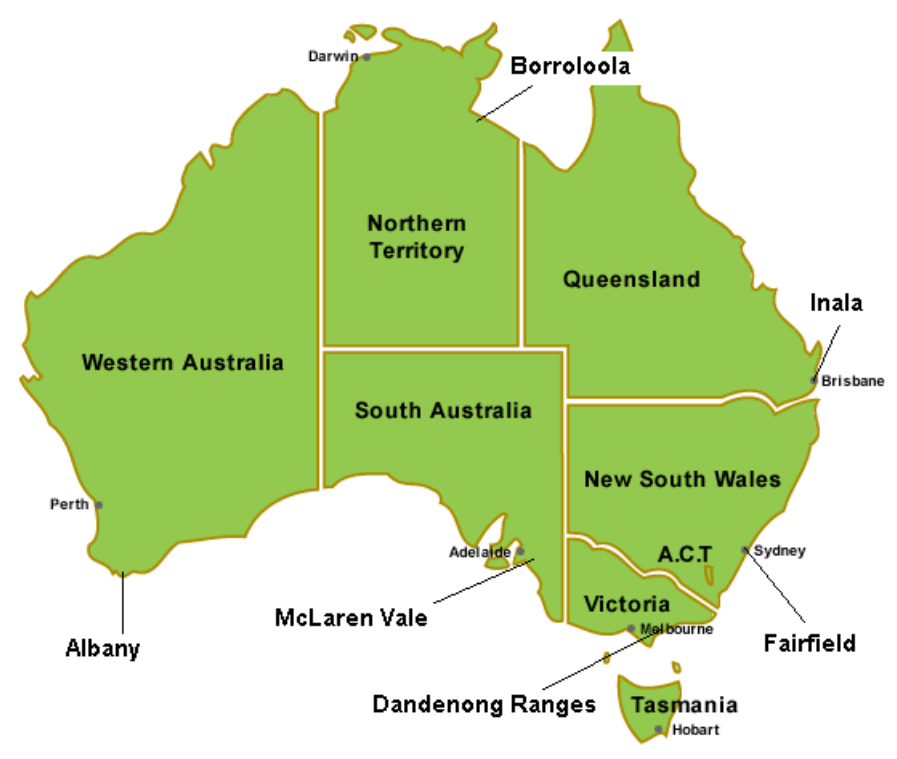

Figure 2: Map of Australia with the music al communities involved in the Sound Links study.

In September 2007 I visited the Dandenong Ranges Music Council Incorporated (DRMC). This is an arts organization located in the foothills of the Dandenong Ranges, approximately an hour's drive east of Melboume. It serves the community of the Dandenong Ranges and Yarra Valley in the Shire of Yara Ranges, and has been funding, facilitating and teaching community music in this region for over 25 years. One month later, I travelled west to Albany, the largest regional city in Westem Australia. It is situated a round a port on its southem coast, $409 \mathrm{~km}$ south of Perth, and is the hub of a 40,000 square kilometre region known as the Great Southem. In December 2007 my colleague Peter Dunbar-Hall and I visited McLaren Vale, a wine region approximately $35 \mathrm{~km}$ so uth of Adelaide in South Australia. The research trip also included the small neighbouring towns of Willunga, Aldinga, Morphett Vale and Kangarilla. Then in February 2008 my colleague Huib Schippers and I visited Fa irfield City in Westem Sydney, an a rea which incorporates 27 suburbs. It is one of the most culturally diverse cities in Australia with more than half of all residents having been bom overseas, mostly in non-English speaking countries. In these settings we searched out 
vibrant community music programs, but also looked outwards to the local schools and explored the connections that they had with the community music groups we studied. We also explored the level of interaction between the different community groups in each location, and how they engaged with the non-musical community a round them. The remaining two case studies include the remote Indigenous community of Borroloola in the Northem Teritory and an urban Indigenous Youth Music Festival in Inala in Queensland.

\section{Critical suc cess factors}

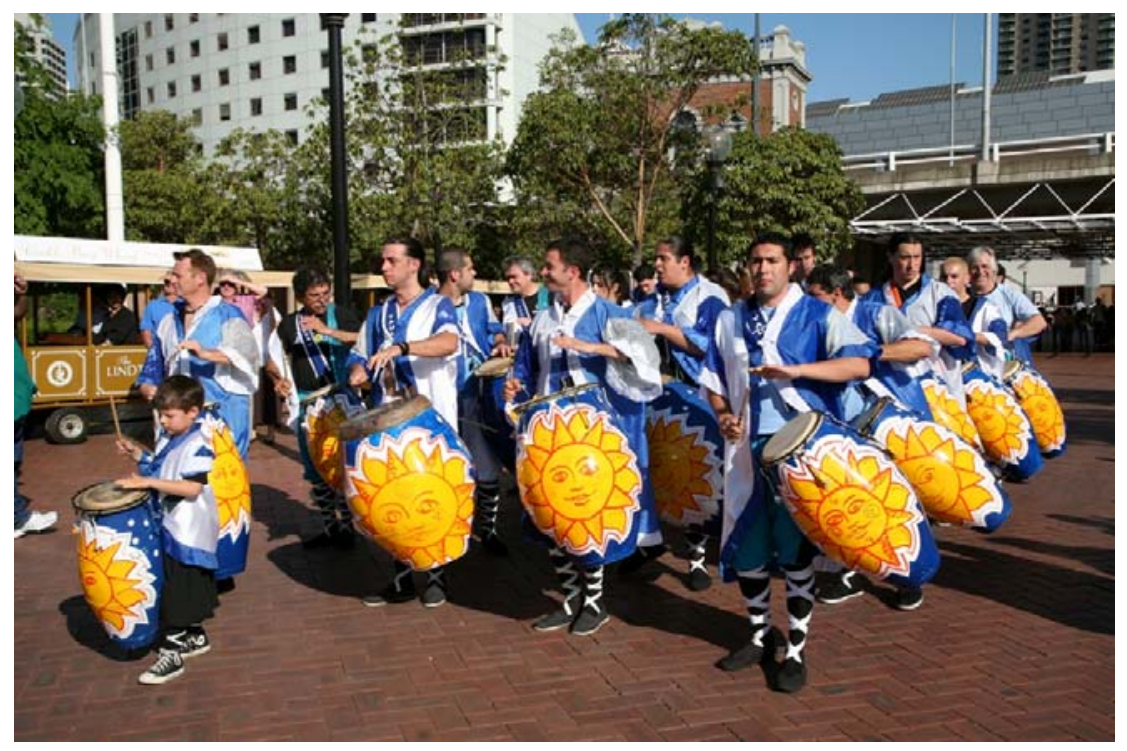

Figure 3: Yauguru, Westem Sydney, New South Wales.

Tonight we're at a rehearsal of the Yauguru Uruguayan drumming group in Westem Sydney. This group gathers every week in a small community hall lined with brightly coloured murals that is affectionately called 'The Shed.' Before the rehearsal begins the hall is abuzz with people amiving and wamly greeting one another. As they tune their drums they laugh and jest about; however, as soon as the rehearsal begins they become highly focused and serious about their playing. The room is vibrating from the resonant sounds of their drumbeats. The dancers then get into formation and begin rehearsing their moves. A profound sense of community is evoked as they engage in musical dialogues with one another; sensitively watching, listening, responding, experimenting, leaming, and exerting themselves. They watch their leaders like hawks, responding attentively to their instructions. As I look around, I notice family members sitting at the sides of the room, tapping their feet, smiling and lost in the music. A baby in a walker is even given a small drum and encouraged to participate. During the break the drummers challenge one another with new rhythms and ideas, and some of the dancers pick up drums and have a go. As we sit down and share a meal of traditional Uruguayan food, they tell us that they see this group as a family; they care for one another and help each 
other out. It gives them a sense of cultural belonging and helps them cope with life's challenges.

(Ba rtleet Field notes, 20 February 2008, Fairfield, New South Wa les)

This fieldnote entry points towards one of the primary aims of this study, which has been to identify critical success factors in these different community settings, and how they can inform the development of models and exemplars for other Australian community and educational contexts. Here I will limit my disc ussion to three of the most significant success factors that were found in the communities studied. A number of other factors - including enhancing community well-being, validating a sense of identity, nurturing intergenerational interaction, encouraging sustainability and ownership, supportive locations, venues, and facilities, committing to equal opportunities and a sense of inclusiveness, and creating a community vision - will be disc ussed in future publications a rising from this study. These factors echo some of the characteristics of community music settings identified in the policy statement of the Community Music Activity Commission of the Intemational Society for Music Education (http://www.isme.org/).

\section{Inspining leadership from within the community}

When the participants in this study were asked what factors contribute towards the vibrancy of their community music activities, oftentimes their first response was to describe the inspiring leadership of an individual community musician or educator who directs the activity they're involved with. They referred to this person's leadership capabilities, musical and administrative expertise, pedagogical skills, inspiration and encouragement. The most respected community music leaders seemed to have a deep understanding of how music connects people not only in their own groups but also within the broader community. A strong community music leader in McLaren Vale, Greg J ohn (Head of Performing Arts at Tatachilla Lutheran College) expla ined:

It's about community building and relationship building and the underpinning thing in all of this is [...] the music. [...] The thread that goes through all this community building around here, where you can get people from the stiff accountant through to the hippy performing together, from an 87 year old to a 13 year old, and the little kids and the mums and dads performing with each other and cheering and saying, 'isn't this wonderful?' and seeing where they can go [...] all of that is only possible because of the music. I don't know any other medium that could do it. (Personal interview, 9 December 2007)

Such leaders are also deeply attuned to the unique needs and concems of people in their local area and have a vision for how they want music to assist their communities to grow. They are highly creative people, who have the ability to find a multitude of different ways to engage the broader community in music. In fact, participants in our study also spoke of the importance of leaders who look beyond their own activities in order to connect with others. This kind of leadership was exhibited by some, but certainly in the minority. After discussing this issue in relation to Fairfield and Huib Schippers' notion that behind every vibrant community music 
program is a 'mad' person; someone who defies all odds and madly devotes their lives to the needs of their community music group, Tiffa ny Lee-Shoy (Senior Polic y Advisor - Cultural Planning, Fairfield City Counc il) commented:

In Fairfield there's very strong bonded social capital, so within the Cambodian community, or within the Chilean community, it's very strong in Fairfield [...]. Perhaps those mad people are the ones who come up with the ideas in those particular community groups, but it perhaps also is that mad person who is mad enough, brave enough, to step out of that bonded group and look for other opportunities for that bonded group and plug them into others. The thing is there are not that many of those bridging people. (Personal interview, 18 February 2008)

Looking at the qualities of the leaders in the four communities we visited, they certainly resonate with those described by Veblen (2002). They lead by example. As a well-known leader in the Dandenong Ranges, Bev McAlister (Executive Office of the Dandenong Ranges Music Council) said:

I like to think, and I can see it happening, that we as the elders, I guess, through community music are showing leadership and setting examples [...] that a lot of young families who come into the hills to live suddenly find themselves involved in helping set up a concert band, taking responsibility for supporting, the Fire Cycle. That Fire Cycle project had over 200 performers, but it would have had a cast of 250 backstage who felt a commitment and showed willingness. (Personal interview, 14 September 2007)

These leaders tend to be highly effic ient communicators and listeners, with the ability to make everyone feel important. They are incredibly well connected to a network of other teachers, musicians, council workers, and so on, and are skilled advocates. They are patient, have a sense of humour, and a loyal commitment to their communities, as well as a generosity of spinit.

\section{Community collaborations}

The most vibrant programs studied were those which connected across community groups and out into the broader community. As one might expect, such collaborations seemed to occur more frequently in smaller regional towns, where due to their smaller populations there was more interaction amongst musicians and groups. In such cases, community groups were interacting with one another on different levels, sometimes sharing concerts, other times sharing rehearsal venues, or working on large scale productions or festivals. In such instances, these community groups pooled together their financial resources, equipment and personnel to serve mutually beneficial purposes. Sometimes this was formalized and other times it occurred on a relatively informal basis. More often than not, these collaborations were formed by virtue of the groups having members in common.

While some of the community collaborations studied do occur on a regular basis, the most striking examples appeared to occur through flagship community events, which involved partic ipation from the broader community beyond only music-makers. A striking example of this was found in the Dandenong Ranges with their Fire Cycle project, which culminated in a major 
community performance in 2005 . The project was created in consultation with the community and was designed to educ ate and heal the community after a number of serious fires had taken both homes and lives in the area. It involved community song writing workshops with composers, commissioning of new music especially composed for the project, visual arts and dance to tell the community's fire stories, the production of a Fire Education music CD with fire brigades and community musicians, the premiere performance of the 'Song of the Fireys (We're Not Heroes)', a fire fighters torchlight parade at the Knox Festival, and the Fire Cycle Finale Concert at Belgrave Heights Convention Centre on October 8th and 9th, 2005. This project involved a range of local community singers, musicians, dancers, visual artists, circus performers, professional musicians, composers, choreographers and school students. It also included Parks Victoria, the Country Fire Authority, Shire of Yarra Ranges, environmental groups and emergency services personnel, the Community Forest Project and volunteer helpers and stage crew. The inspiration for this project came directly from current environmental issues facing the community and appeared to spawn new projects that looked at different environmental issues, such as water conservation. Students from the Femy Creek Primary Sc hool spoke about the exc itement they felt being part of a big project with other schools, older people, and inspining figures from the community such as the local fire-fighters. When I asked them about the importance of making music that relates to local community issues such as fire, a young student explained, 'I think it's really good because kids, especially, they don't really want to sit and hear people ramble on about this happened this time [...] so it's more interesting, especially to like children, to actually hear it in a different way.' Another student intemupted and said, 'Yeah. With music it's a lot harder to switch out than if someone's just ta lking' (Foc us group interview, 13 September 2007).

\section{Embrac ing c ultural diversity}

While the first three musical communities studied appeared to be largely monocultural (in the sense of Caucasian Australians with a primarily Anglo-Saxon frame of reference), the Fairfield case study provided a contrasting perspective due its cultural diversity. While the other three communities were certa inly vibrant in terms of music-making and engaged large proportions of the local community in their activities, the nature of the music-making that was observed was primarily Westem, although not always classical, in nature. Traditional bands, orchestras and choirs prevailed in all these contexts, but so did popular music, jazz, folk music, country music, pipes and drums, and so on. However, little cultural diversity was expressed through music, and when it was - for instance with Indigenous musicians - it was usually occuming on the margins. While this type of Westem music activity was also present in Faiffield, the community's cultural diversity stood out as its defining feature. This was also strongly linked to its economic make-up: Fairfield is known for its affordable housing and social services for recent migrants. While this may not necessarily reflect the musical life of the other three case studies in this a ric le, this noteworthy feature of music in Fairfield significantly sheds light on the ways in which community music operates in cultura lly diverse parts of Australia.

In Fairfield we observed a very strong connection between local musicians' cultural identities and their chosen community music activities. Many spoke of the ways that music gives people, 
young and old, a means to express their cultural identity and feel a sense of pride about who they a re and where they come from. As Ramphay Chittasy from the local Lao Temple expla ined to me:

In the Westem society people are always rushing, but when we come here to the temple the young people leam about being graceful. The minute they put the costume on they don't run anymore [...] and they leam how to move their fingers to go along with the music, so it all synchronizes, the teacher, the drum, everything, the music, girls, and boys. It brings out the spint of the music and you can feel it with goose bumps, you know. It brings back something from our country, which is really needed. When you go out and say, where are you from? I say l'm from Laosand I'm very proud that we have something to treasure [...]. (Foc us group interview, 21 February 2007)

A number of other 'older' participants also spoke about the value of music in connecting the generations and 'passing their culture on'. Young people from particular cultures, such as the Pacific Islands, seemed to be accustomed to this, possibly due to their heavy involvement in singing at church and at home. Other children, such as a Vietnamese children's singing group, seemed to enjoy the opportunity to leam the language that their parents speak at home through music. Some of the most vibrant community groups a lso spoke about their organizations in familial terms, discussing the ways in which a sense of cultural community and family is nurtured through their music-making together. Interestingly, many community music groups also provided 'traditional' food to their members, and this also nurtured a social aspect to the rehearsals.

\section{Leaming dynamics}

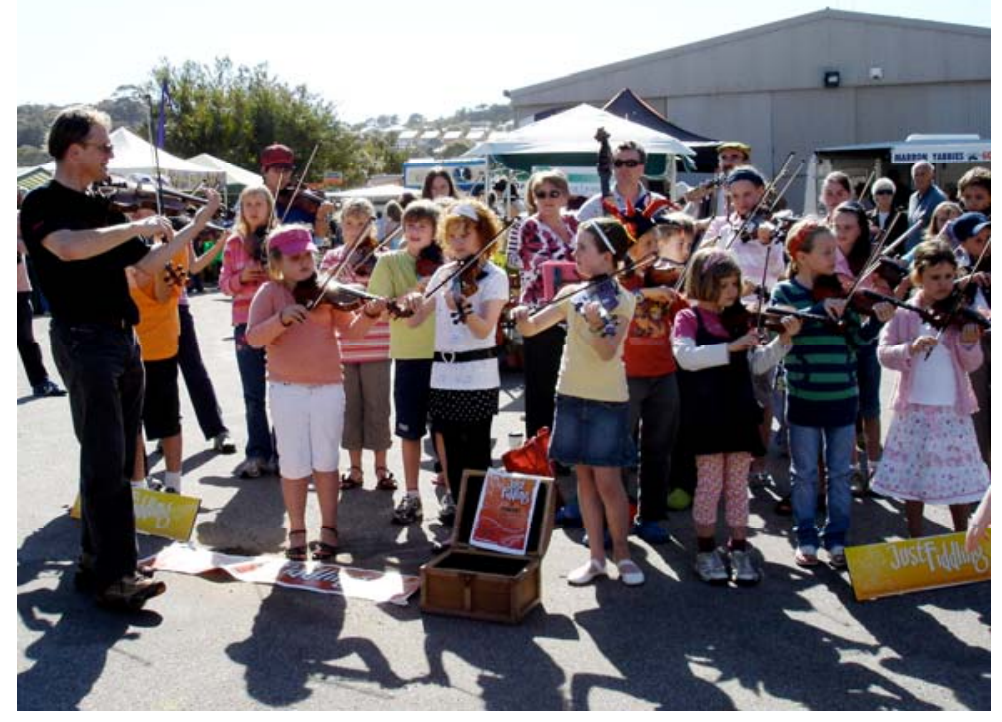

Figure 4: J ust Fiddling, Albany, Westem Australia .

It's the crack of dawn and I am at the Famer's markets, a temporary set up behind the local church in Albany. The J ust Fiddling group are performing to busk and advertise their 
concert later tonight. The early moming sun is glaringly bright but wam and energizing. As the large crowd of locals meander around the markets buying fresh produce, the group play a program of gigs and reels. They're dressed in everyday clothes and are made up of young beginners, advanced high school students and local music teachers. The three leaders circle the outside of the group demonstrating the fingerings and bowings to the beginners in the front row and then urging the more advanced players to speed up the tempos. Small children in the audience dance to the music as their parents catch up with friends. As the music gets more difficult the young ones sit down on the floor with their fiddles in their laps, and watch, listen and leam from the more advanced players. In this community setting, strong models of both formal and informal leaming and teaching are evoked as the musicians perform for their local community.

(Bartleet Fieldnotes, 13 October 2007, Albany, Westem Australia)

As this fieldnote entry suggests the second primary aim of this study has been to examine the types of leaming and teaching found in Australian community music contexts, and how they can contribute towards an expanded view of music education in this country. The concept of leaming is clearly integral to community music and the notion of community is clearly integral to music leaming and teaching. As J orgensen explains:

One of the most pervasive models underlying music education is that of community. Whether it be the Hindustani sitarist instructing his disciple in traditional manner, the Westem classical pianist conducting her masterclass, the Australian Aboriginal songman teaching his young kinsman a love song, or the Balkan mother singing her daughter a lament, all participate in a community in which music making and taking plays a central role. (1995: 71)

Likewise, Wood \& J udikis suggest:

One cannot belong to a true community without lea ming in the community and from the community. [...] every community educates - in making its decisions, in developing or agreeing upon values, in determining cultural noms, in negotiating differences among members and with other communities, and even in the everyday unstructured interactions and communic a tions among community members. (2002: 112)

Of particular interest to this study is the ways in which people leam in community music settings and how these approaches can offer altematives to the current methods of leaming and teaching found in many Australian school settings.

In each of the four musical communities visited, a number of different leaming and teaching methods were observed. These ranged from traditional aural transmission, to experimental leaming, to strongly technology-based ways of leaming. While some were more structured with set rehearsal and perfomance schedules and administrative infrastructure, others were more unstructured and 'ad hoc' where community members could simply 'drop in' whenever they wanted to make music. While we did observe a diverse range of infomal leaming methods 
across these different community contexts, we also discovered a number of more formalized situations - where a facilitator took on the role of 'the teacher', thereby defining the others as 'students' (Folkestad 2006: p. 142). Sometimes this was because the facilitator was a school teacher and accustomed to a more fomalized approach to leaming, and other times, in more culturally diverse settings, this was because the facilitator was an 'elder' and teacher of their cultural traditions. It would seem the most vibrant programs showed awareness and flexibility when it came to finding their positions on this spectrum of a pproa ches (see J a ffurs 2006).

A striking example of this was observed in the contemporary music program Recipe for Jam run at the Vancouver Arts Centre in Albany. In October 2007 fifteen emerging musicians gathered together for a one week residential music program that culminated in a free public performance. Mixing jazz, hip hop, rock, heavy metal, folk and roots they created the 'right recipe' of music to captivate one another and their local community. The program included workshops on song writing and instrumental skills with experts, and jam sessions with guest artists and bands. As it was a live-in program, there were large amounts of time for jamming and experimenting across different genres. In these cases the leaming was based on a peer leaming model that was clearly self-directed, where participants felt a sense of common purpose, assumed mutual responsibility, respected the individual differences a mong members, committed themselves to the well-being of each other and the group, and had a sense of ownership over the music. As a partic ipant M. J. Rogers, a self-described 'metal-chick' expla ined:

There are so many genres, from metal to pop and the fact that you throw them in a house together [...] but the fact that we got along together and collaborated together [...] the diversity is pretty much what a mazes me. [...] Very eye-opening; nomally music genres tend to hang out together, but to be thrown into every genre at once is such a great experience. Like before, I'd never known how to structure a jazz song or known what's a blues chord, but just sitting there watching people do it, you just take it all in. [...] That's why I couldn't sleep, the music was just permanently there, it was all different styles, you know. (Personal interview, 14 October 2007)

This self-directed approach resonates with Mullen's statement that what excites him is the 'way that the practice of community music seeks to move away from the expert teacher and willing pupils model of music transmission to a more dynamic and interactive community of participants' (2002: n.p.). M. J. went on to describe how they each were teachers of their own styles and leamers of the others, often changing roles. As Veblen reminds us 'a reoccuming theme in musical communities concems the fluidity of knowledge, expertise, and roles, with individuals partic ipating in va rious ways from observer, to partic ipant, to creator, to leader' (2004: n.p.).

In the case of Recipe for J am motivation to participate and leam was sparked by fun, friendship, identity formation, exploration and ownership of the music. Such elements then motivated these participants to pursue their musical collaborations after the week had finished and form new groups. These are elements echoed by Green: 
Not only do identity, friendship and enjoyment go hand-in-hand with motivation, but they are also intrinsically and unavoidably connected to particular ways of leaming: playing by ear, making both close copies and loose imitations of recordings by professional musicians who are respected and admired, transforming what is 'picked up' into a piece of music, improvising, jamming and composing with friends, attempting to create music that both fits in with and is distinct from the sounds one enjoys hearing a round [...]. (2001: 216)

The examples that Green gives resonate strongly with those found in the Recipe for Jam program, but were also observed in a number of the other community settings we researched; such as a group of 'at risk' young people collaborating on their hip hop tunes in a 'drop in' community centre studio, a folk club session where people shared their latest songs and compositions with one a nother in a large circle, a group of pipers sitting around a table imitating their leader who was reading music from an intemet download, and a drumming circle that played by earand experimented by improvising with one another.

Many of the educators in this partic ular study a lso spoke about the benefits of leaming music in a community environment. In such settings community music activities a re not bound by restric tive curic ula, standards and assessment needs. Instead, music ians a re able to enjoy a greater sense of creativity and flexibility, with the opportunity to leam alongside people of different ages, abilities and backgrounds. Other educators saw community music activities as a healthy supplement to what is currently being offered by schools, particularly in circumstances where schools are lacking in resources and specialist teachers. However, these educators were also keen to point out that this doesn't necessarily flow in one direction; often healthy school programs nourish healthy community music programs, by contributing teachers and students with high musical competencies. In fact, a number of the teachers we interviewed were also actively involved in music-making in their communities, not only as facilitators, but also as partic ipants. 


\section{Models for community-sc hool collaborations}

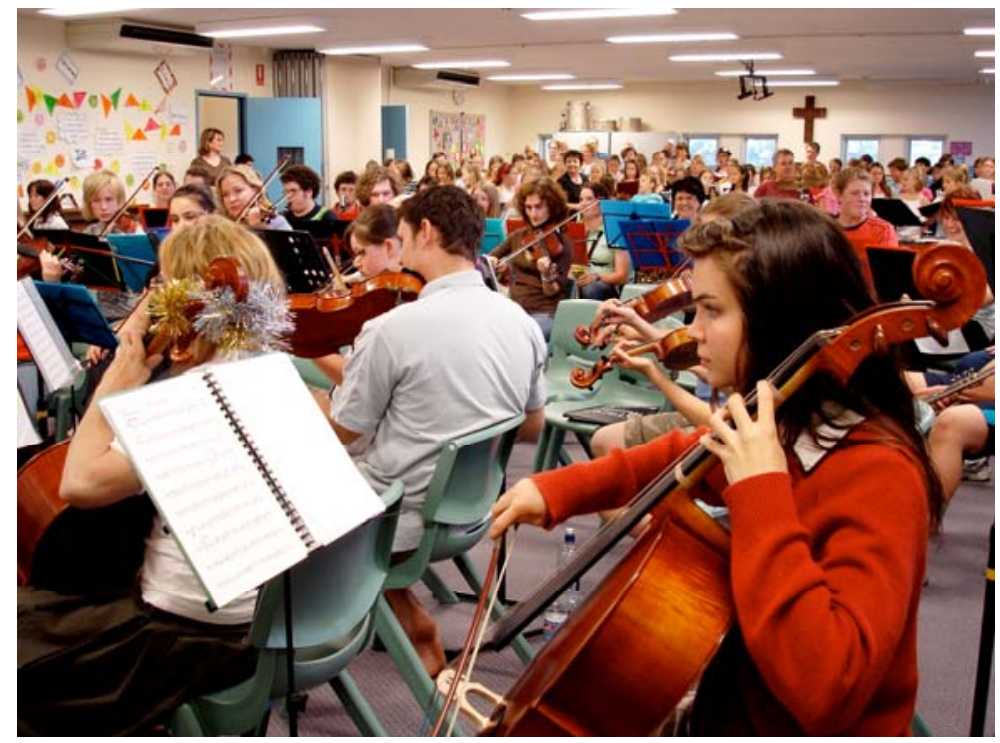

Figure 5: McLaren Vale Community Carols Rehearsal, Tatachilla Lutheran College, South Australia.

It's the final rehearsal for the community carols concert in McLaren Vale. There is an excitement abuzz in the air. The musicians a re full of the festivities of the season and tinsel and decorations adom their music stands and instruments. This is a large-scale schoolcommunity production, with hundreds of school students and community members making up the orchestra, men's choir, ladies' choir, children's choir, Taiko drumming group, and ballet troupe. From the youngest musician of 7 years to the oldest music ian of 70 years, all are working towards a common musical purpose and looking forward to the big event. Many families are involved in this production, some with as many as three generations participating. Recent a lumni of the school who have left the town to study at university have also come back to participate in this seasonal event. School teachers take the lead with the ensembles and community members help with the organization of music, equipment and the overall production. In a few days time the school oval will house this annual event, and draw in a crowd of over 2000 people.

(Ba rtleet Fieldnotes, 5 December 2007, McLaren Vale, South Austra lia)

As this final fieldnote entry indicates, the third primary aim of this study has been to examine vibrant models for community-sc hool collaborations, and how they can enrich both the offerings of school music programs and the activities of community groups. The need for such connections and collaborations, partic ularly in the lives of young Australians, is a dvocated by Temmeman:

A central issue for all involved in the musical education of young people is how to connect the three contexts of the school, home and community to enhance positive attitudes towards music making, to build on existing opportunities to engage in music 
making, and to bring together the wealth of music activity, resources and expertise. The question 'why connect?' is well answered by the fact that music plays an important role in young people's lives and that school, home and out-of-school music al experiences all contribute in important, differing ways.

(2005: 118-119)

The connections that Temmeman speaks about still need to be improved in the Australian context; however, there is a wealth of intemational discourse on such educational improvement efforts, where educators have launched many initiatives to bring the community into the school, take school programs and activities into the community, and create communities of leaming within the school itself (Decker \& Decker 2003: 27). However, such efforts have not always succeeded, and schools have ended up functioning autonomously and communities have rejected the school's efforts at outreach. In such cases, Camuthers argues that the school suffers the most: 'The community may remain unscathed by a school's insula rity but the reverse is rarely true' (2005: 3).

In terms of building these community-school partnerships so that they a re sustainable, dynamic and successful, Decker \& Decker (2003: 115-116) suggest that having a collaborative vision in decision making from the beginning and a clear structure for communication are crucial. They a lso suggest that acknowledgement of the specia lities of the collaborating partners, and clearly defined roles and responsibilities, are important; as are clear goals with a method of measuring success, adequate funding, and an active connection with the local neighbourhood and political processes. Looking at the models for school-community collaborations that we've observed in the four communities so far, I would also add the need for a shared sense of ownership, flexibility and engagement with multiple community organizations beyond those involved in music and education, and a suitable venue that supports the collaboration. Of course there isn't a single model for developing such educational connections. The different levels of involvement and partnership will clearly vary from school to school depending on the local needs and circumstances.

A striking example of one of these community-school collaborations was found in the Dandenong Ranges. This collaboration works on a number of levels from the day-to-day to larger project-based work. The DRMC's music centre is located at Upwey High School in a building which was refurbished for this specific purpose. Some of the school's instrumental and vocal music lessons occur in this building, and as a result, the DRMC is very accessible and visible because of this connection. Its permanent location on the school grounds is also beneficial in any grant or funding applications they submit; this physical pemanency shows that the organization won't fold easily, has a sense of outreach, is sustainable, is visible, has a commitment to education and young people, and is worth funding. The school also provides a steady stream of students into the music activities run by the DRMC, such as after school lessons, evening ensembles, and major community projects. The school is also heavily involved in a number of the major projects that are run by the DRMC, not only providing students but also 
support and assistance from school teachers and administration. Some of these projects have also been the inspiration for new and innovative approaches to the music cumic ula. Speaking to those involved in both the DRMC and the school, it is clear that it is a mutually beneficial relationship. The principal of Upwey High School, Greg Holman, described it as:

Extremely effective; it's one that is based on a mutual understanding of the needs of the community of the school [...] and the needs of education especially in music [...]. It's supportive and both parties are supportive of each other. Both parties understand each other's needs. It's reliant on outside grants and self-funding [...]. It's a model based on trust and cooperation. Without the trust I don't think we'd be able to sustain it. [...] We see it as another resource for teaching staff to use that provides music education that wouldn't be available to some students. From a provisional point of view it's a very important educational organization because not all schools can provide music education. (Personal intenview, 11 September 2007)

As Greg Holman suggests, the benefits of building such partnerships a re wide ranging; from an improvement to the school's cumic ula and the quality of leaming, to other factors which were mentioned later in the interview, such as the active involvement of parents and families in student leaming, the professional development of teachers, community leaders, and musicians (see Dreeszen, Aprill \& Deasy 1999: 3-4). In terms of parental involvement, a nother striking model was found at the Community Carols run by Tatachilla Lutheran College in McLaren Vale. In this setting, parents, teachers, students and community members all work collaboratively to form various choirs, instrumental groups and a large-scale orchestra for this event every year. The model is driven by a commitment from the school towards intergenerational leaming and community outreach.

\section{Conclusions}

While this paper has provided a brief and cursory glance at some of the key issues which are emerging in the Sound Links project, it has aimed to begin addressing some of the gaps in our understanding of the cultural, social and education dynamic s of community music in Australia. The examples discussed in this article certa inly illustrate the vibrancy and diversity of community music activities in this country. They highlight the value of inspiring lea dership in community music programs, the benefits of community music-making for personal health and well-being, and the ways in which community music encourages people to positively express their sense of cultural identity. They also allude to the significant role community music plays in connecting the generations through a shared and creative leaming process. The role that cultural diversity plays in the vibrancy of community music programs in Australia is also apparent, as is how inclusive community music programs are, regardless of people's abilities. These examples also emphasize the benefits of collaborating with the broader community, and the importance of careful planning to ensure such collaborations are productive. By bridging the divide between organized and 'ad hoc' activities, between structured and unstructured ways of leaming and performing music; a number of the examples in this article also suggest possible ways in which 
school-community connections can be nurtured and strengthened to enhance the vibrancy of music-making throughout the country.

\section{References}

Amit, V., \& Rapport, N. (2002), The Trouble with Community: Anthropological Reflections on Movement, Identity and Collectivity, London: Pluto.

Australia Council (2001), Planning for the Future: Issues, Trends and Opportunities for the Arts in Australia, Surrey Hills, NSW: Australia Council.

Australia Council (2000), Austra lians and the arts: What do the arts mean to Australians Overview, Surrey Hills, NSW: Australia Council.

Behar, R. (1999), 'Ethnography: Cherishing Our Sec ond-Fid dle Genre', J oumal of Contemporary Ethnography, 28: 5, pp. 472-484.

Breen, M. (1994), 'Constructing the Popular from Public Funding of Community Music: Notes from Australia', Popular Music, 13: 3, pp. 313-326.

Cahill, A. (1998), The Community Music Handbook: A Practic al Guide to Developing Music Projects and Organizations, Sydney: Currency Press, in association with the Music Counc il of Australia.

Camuthers, G. (2005), 'Community Music and the "Musical Community": Beyond Conventional Synergies', IntemationalJ oumal of Community Music, [Electronic Version] C: Retrieved April 27, 2007 from http://www.intljcm.com/ind ex.html.

Coffman, D. D. (2006), 'Voic es of Experience: Interviews of Adult Community Band Members in Launceston, Tasmania, Austra lia' Intema tional J oumal of Community Music, [Electronic Version], D: Retrieved April 27, 2007 from http://www.intljcm.com/index.html.

Decker, L. E., \& Decker, V. A. (2003), Home, School, and Community Partnerships, Lanham, Md.: Sc arecrow Press.

Department of Education, Sc ience and Tra ining (DEST) (2005), Report of the National Review of School Music Education. Canberra: Australian Govemment, Department of Education, Sc ience and Training.

Dreeszen, C., Aprill, A., \& Deasy, R. J . (1999), Leaming Partnerships: Improving Leaming in Schools with Arts Partners in the Community, Washington: Arts Educ a tion Partnership.

Dunn, A. (2006), Community Partnerships Scoping Study Report: Creative Communities, Sydney: Australia Council.

Elliott, D., Higg ins, L., \& Veblen, K., eds. (2008), Intema tional J oumal of Community Music, 1: 1, pp. 3-4.

Folkesta d, G. (2006), 'Formal and Informal Lea ming Situations or Prac tices vs Formal a nd Informa I Ways of Knowing', British J oumal of Music Education, 23: 2, pp. 135-145.

Green, L. (2001), How Popular Musicians Leam: A Way Ahead for Music Education, Burlington, Vt.: Ashgate.

Ha mison, G. (1996), 'Community Music in Australia' in M. A. Leglar (ed.), The Role of Community Music in a Changing World: Proceedings of the Intemational Society for Music Education, 1994 Seminar of the Commission on Community Music Activity, Athens, GA: University of Georgia Press, pp. 39-45. 
Hawkins, G . (1993), From Nimb in to Mardi Gras: Constructing Community Arts, St. Leona rds, NSW, Australia: Allen \& Unwin.

Higgins, L. D. (2006), Bounda ry-wa lkers: Contexts and Concepts of Community Music, University of Limerick: Limerick.

J affurs, S. E. (2006), 'The Intersection of Informal and Formal Music Lea ming, Intemational J oumal of Community Music, Practic es', [Electronic Version] D: Retrieved April 27, 2007 from http://www.intljc m.com/index.html.

Jorgensen, E. R. (1995), ‘Music Education as Community' , Joumal of Aesthetic Education, 29: 3, pp. 71-84.

Levesque-Lopman, L. (2000), 'Listen and You Will Hear. Reflections on Interviewing from a Feminist Phenomenologic al Perspec tive', in L. Fisher (ed.), Feminist Phenomenology, Dordrec ht: Kluwer Academic Publishers, pp. 103-132.

Mason, A. (2000), Community, Solid a rity and Belonging: Levels of Community and their Noma tive Signific ance, Cambridge, U.K.: Cambridge University Press.

Mullen, P. (2002). We don't teach we explore: Aspects of community music delivery. Paper presented at the Intemational Soc iety for Music Education Seminar of the Commission on Community Music Activities, Rotterdam, The Netherlands. Retrieved April 27, 2007 from http://www.world music centre.com/uploads/cma/mullentea c hexplore.PDF .

Myers, D. (1992), 'Teaching Leamers of all Ages', Music Educators J oumal, 79: 4, pp. 23-26.

Tedlock, B. (2000), 'Ethnography and Ethnographic Representation', in N. K. Denzin \& Y. S. Lincoln (eds.), Handbook of Qua litative Research (2nd ed.), Thousand Oaks, Ca lifomia: Sa ge Public ations, pp. 455-486.

Temmeman, N. (2005), 'Children's Partic ipation in Music: Connecting the Cultural Contexts - an Austra lian Perspective', British J oumal of Music Educ ation, 22: 2, pp. 113-123.

Veblen, K. (2004), 'The Many Ways of Community Music', Intemational J oumal of Community Music, [Electronic Version] A: Retrieved April 27, 2007 from http://www.intljcm.com/index.html.

Veblen, K., \& Olsson, B. (2002), 'Community music: Toward an Intemational Overview', in R. Colwell \& C. Richardson (eds.), The New Handbook of Research on Music Teaching and Lea ming, New York: Oxford University Press, pp. 730-753.

Wood, G. S., \& J udikis, J . C. (2002), Conversations on Community Theory, West Lafayette, Ind.: Purdue University Press.

An ea rlier version of this artic le appeared in /CMA XI: Projects, Perspectives \& Conversations: Proceedings from 2008 Seminar of the Commission for Community Music Activity.

\section{Contributor details}

Dr Brydie-Leigh Bartleet is a Research Fellow at the Queensland Conservatorium Research Centre and Lecturer at the Queensland Conservatorium Griffith University, where she is working on the ARC funded project, 'Sound Links: Exploring the dynamics of musical communities in Australia and their potential for informing collaboration with music in schools'. At the Conservatorium she teaches courses in twentieth-century music, critical musicology, qualitative research methods, 
popular culture, and women's music. She has worked as a sessional Lecturer at the University of Queensland, and as a freelance conductor has worked with ensembles from Australia, Thailand, Singapore and Taiwan. She has published widely on issues relating to community music, women conductors, peer-leaming in conducting and feminist pedagogy, and is currently editing two books on music research and music education.

Contact: Queensland Conservatorium Research Centre, Griffith University

P O Box 3428, South Bank, Q ueensland, 4101, AUSTRAШA

E-mail: b.bartleet@griffith.edu.au 